Article

\title{
Judith and Holofernes: Reconstructing the History of a Painting Attributed to Artemisia Gentileschi
}

\author{
Anna Impallaria ${ }^{1,2,3, *, t, \neq(\mathbb{D}, \text { Ferruccio Petrucci }}{ }^{1,2,3, \ddagger}$ and Simone Bruno ${ }^{2}$ \\ 1 INFN-Ferrara, via G. Saragat 1, 44122 Ferrara, Italy \\ 2 Department of Physics and Earth Science, University of Ferrara, via G. Saragat 1, 44122 Ferrara, Italy \\ 3 Teknehub-Ferrara Tecnopole, via G.Saragat 13, 44122 Ferrara, Italy \\ * Correspondence: impallaria@fe.infn.it \\ † Current address: INFN, via G.Saragat 1, 44122 Ferrara, Italy. \\ $\ddagger$ These authors contributed equally to this work.
}

Received: 24 June 2019; Accepted: 19 July 2019; Published: 25 July 2019

\begin{abstract}
Recently, a new painting attributed to Artemisia Gentileschi was found in Ferrara, representing Judith exposing the head of Holofernes. Some analyses have been required to verify the history of this canvas, because another known painting is very similar to this one with the exception of the heads of Judith and Holofernes. This last has been attributed to the father of Artemisia, Orazio Gentileschi. Many diagnostics were performed, starting from imaging techniques: from raking light, to UV fluorescence and X-ray radiography. All of them highlighted peculiarities concerning above all the head of the main female protagonist. The results suggest that the face of Judith was subjected to various reworks in the same artistic period because of the original materials still present. This is the reason for the peculiar fragility and, due to this, the restoration of the 20th Century focused on Judith's face. However, in this contribution, we want to highlight the results obtained with XRF spot analysis. Indeed, the artistic palette and the restoration materials have been characterized. For example, reds are in cinnabar, while Judith's lips have been restored with cadmium red. The more interesting results regard the use of umber earths. In the painting, this iron-based pigment, rich in manganese, was revealed several times, and the correlation between Fe and Mn was easily verified. More than one correlation has been found due to the use of this pigment to darken the hues.
\end{abstract}

Keywords: painting; Artemisia Gentileschi; imaging techniques; X-ray radiography; XRF; artistic palette

\section{Introduction}

Artemisia Gentileschi (1593-1652) became the foremost female Italian painter thanks to her extraordinary personality. She reinterpreted Caravaggio's style in her own way, working in Rome, Florence, Naples, London, and most probably, in Genoa and Venice as well [1].

Daughter of Orazio Gentileschi, Artemisia began to paint at a young age in her father's workshop, collaborating with him and often deducing themes from his paintings [2]. Soon after, she approached Caravaggio's style and moved to Florence in 1614, where she got in touch with the Tuscany tradition and mannerism. For all her life, she adapted the main artistic movements to her personal style, inspired by great artists of the period, such as her father Orazio Gentileschi and Caravaggio, as well as Rubens and Van Dyck [2].

In her career, she often depicted heroines inspired by the Old Testament. For this reason, the theme of "Judith and Holofernes" was illustrated several times. The most famous painting of Artemisia is probably 
Judith beheading Holofernes (1612-1613), conserved in Naples at the National Museum of Capodimonte. A second edition (1620) of the same theme is conserved in Florence at Uffizi Gallery.

The painting we analyzed is Judith with the head of Holofernes, Figure 1a, attributed to Artemisia Gentileschi and conserved in Ferrara. It represents Judith who is showing the head of Holofernes, with the maid holding a bag. Its peculiarity is the high similarity with a painting attributed to Orazio Gentileschi (Figure 1b) painted with the help of Artemisia [3] and conserved in a private collection in Milan. It is Artemisia's peculiarity taking inspiration from her father's works of art, and this may be the cause of the similarity between the two paintings [2].

The two paintings show the same composition: the maid and the dress of Judith are the same (except for the red cloth in Artemisia's and blue in Orazio's); the head of Holofernes is only a sketch in Orazio's painting; but the real difference lays in Judith's face.
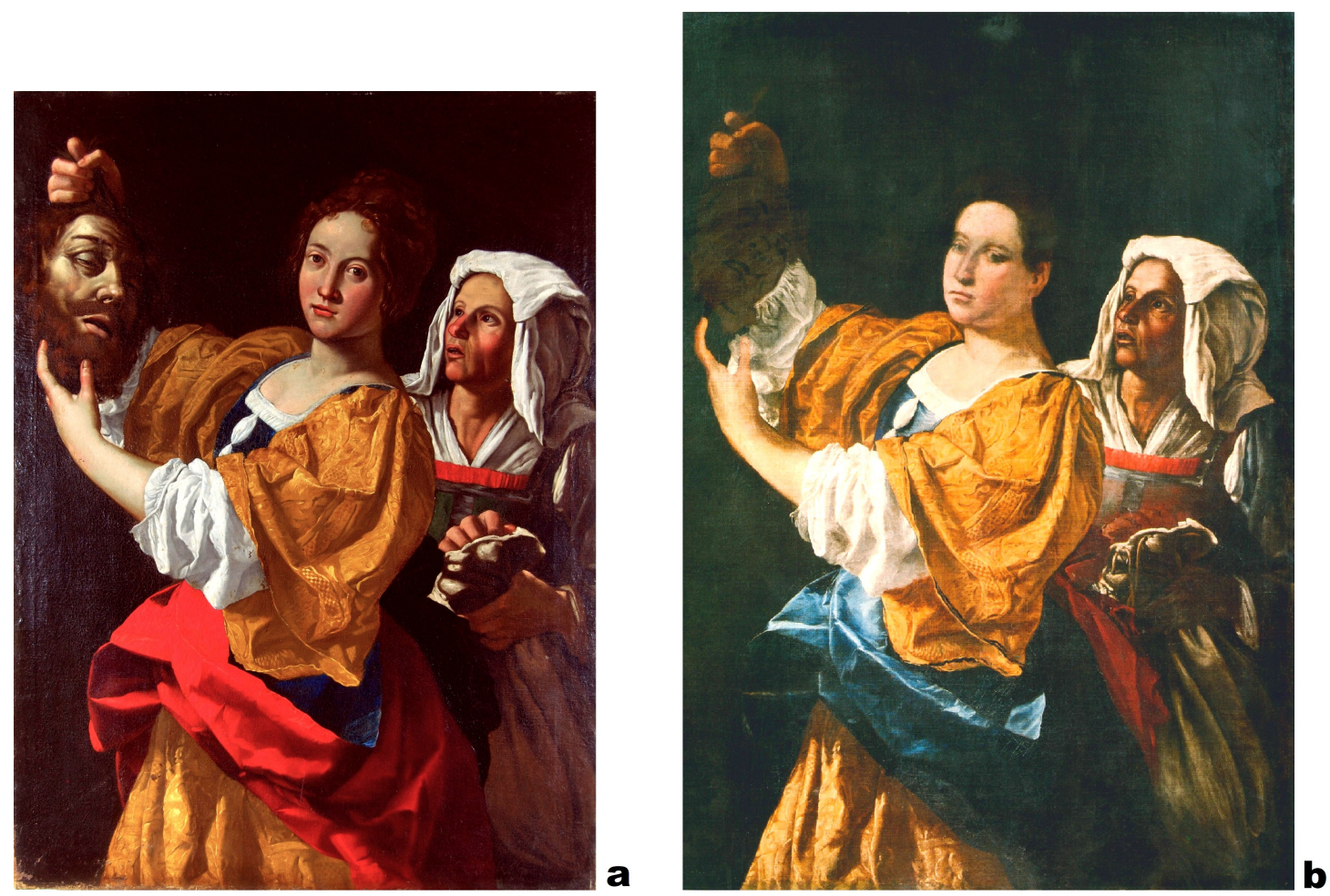

Figure 1. (a) Attributed to Artemisia Gentileschi, Judith with the head of Holofernes, 17th Century, oil on canvas, $97.5 \times 133 \mathrm{~cm}$, Ferrara, private collection. (b) Attr. Orazio Gentileschi, Judith with the head of Holofernes, 17th Century, oil on canvas, $114 \times 145 \mathrm{~cm}$, Milan, private collection. From [3].

Due to the similarity between these two paintings, the question posed by art historians was focused on Judith's face: was it made contemporary to the rest of the painting?

The Laboratory of Archaeometry of the Department of Physics and Earth Science, University of Ferrara, and of the INFN (National Institute of Nuclear Physics)-CHNet (Cultural Heritage Network), Unit of Ferrara, have taken charge of the non-invasive analyses of the painting. We analyzed only the Judith with the head of Holofernes attributed to Artemisia Gentileschi, with noninvasive techniques, namely raking light, UV fluorescence, X-radiography, and X-ray fluorescence (XRF), to identify the artistic materials preliminarily. We did not analyze Orazio's painting, conserved in Milan. 
In this paper, we present the main results, which concern the presence of a pentimento in Judith's face, the presence of a 20th Century restoration located in the same area, and the determination of the artistic palette.

\section{Materials and Methods}

\subsection{Imaging Techniques}

Various imaging techniques have been used to study the conservation state of a work of art, its history, and the painting technique. The documentation and the raking light photography highlighted the painted surface, looking at the presence of strange elements around Judith's face that could indicate a pentimento, or the hand of other artists.

To reveal the presence of previous restorations and the distribution of organic compounds, such as varnishes, we applied UV fluorescence photography with a large Wood's lamp (UV emission centered at $365 \mathrm{~nm}$ ) and a Nikon D50 digital camera equipped with an amber 85b filter. The amber filter was employed in order to cut the reflection of the parasitic visible light.

X-ray radiography is one of the most used imaging techniques, because it gives information about all the painting's layers, their conservation state, the pictorial technique, and the presence of pentimenti, or other subjects underlying the visible ones.

The radiography of Judith with the head of Holofernes was obtained at the Department of Physics and Earth Science, University of Ferrara, by the use of the mobile radiographic scanner developed by INFN-CHNet and University of Ferrara. The instrument [4] was composed by two units, one for the detector motion, the other for the X-ray tube motion, thanks to four Omron Electronics G5 servo motors. The units were in aluminum and their weight around $55 \mathrm{~kg}$ each. The reduced dimensions of each unit $(1.40 \times 1.53 \times 0.74 \mathrm{~cm})$ allowed the scanning of an area of almost $1 \mathrm{~m}^{2}$. Even if the scanning area was limited, there was no limitation in the dimensions of the painting because there was no mechanical bond between the two units. The X-ray tube used was a Varian M-143 with molybdenum anode. The detector was a Teledyne-DALSA Radeye 200, a CMOS photodiode array coupled with a $\mathrm{Gd}_{2} \mathrm{O}_{2} \mathrm{~S}$ scintillator screen.

The radiography of the whole painting required collecting 266 images, with the X-ray tube set at 24 $\mathrm{kV}$ and $19 \mathrm{~mA}$, without any beam filter. The time of acquisition for each radiographic image was $1 \mathrm{~s}$.

\subsection{Spot Analysis}

In order to identify the pictorial materials, we applied the $X$-ray fluorescence $(X R F)$ technique. This technique reveals the presence of elements above the atomic mass of silicon $(Z=14)$ when working in air, so that the organic compounds were not identified.

The XRF spectrometer used was the Bruker Artax200, working at $50 \mathrm{kV}, 700 \mu \mathrm{A}, 60 \mathrm{~s}$, in air. We collected 74 spectra (Figure 2), considering at least three measurements for each hue and the presence of restorations. 


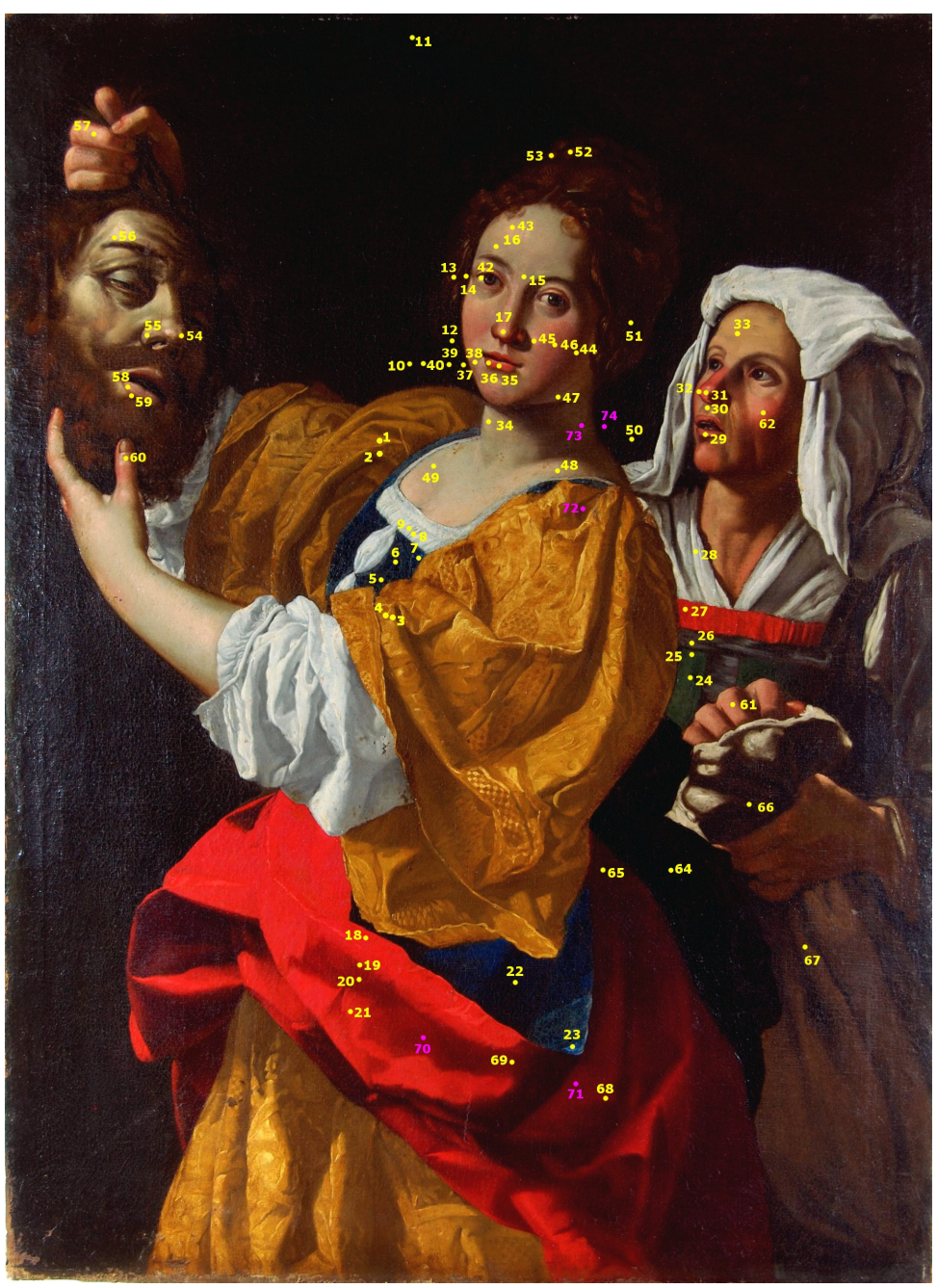

Figure 2. Map of the XRF points acquired on Judith with the head of Holofernes at $50 \mathrm{kV}, 700 \mu \mathrm{A}, 60 \mathrm{~s}$, in air. In yellow, the spectra acquired on the recto of the painting; in pink, the spectra acquired on the verso of the painting.

\section{Results and Discussion}

In this section, the main results obtained on the Judith with the head of Holofernes will be explained. The results obtained with the imaging techniques highlight the history of its conservation and the artistic technique, while the XRF analysis exploits the first interpretation of the materials used by the artist.

\subsection{Imaging Techniques}

The imaging techniques employed provided information about the history of the painting from a conservation point of view and the artistic technique. Starting with the simplest one, the raking light showed a uniform craquelure through all the painted surface. Focusing on Judith's face (Figure 3), in the raking light photography $(\mathbf{b})$, the craquelure seemed to follow the border of the left side of the face. 

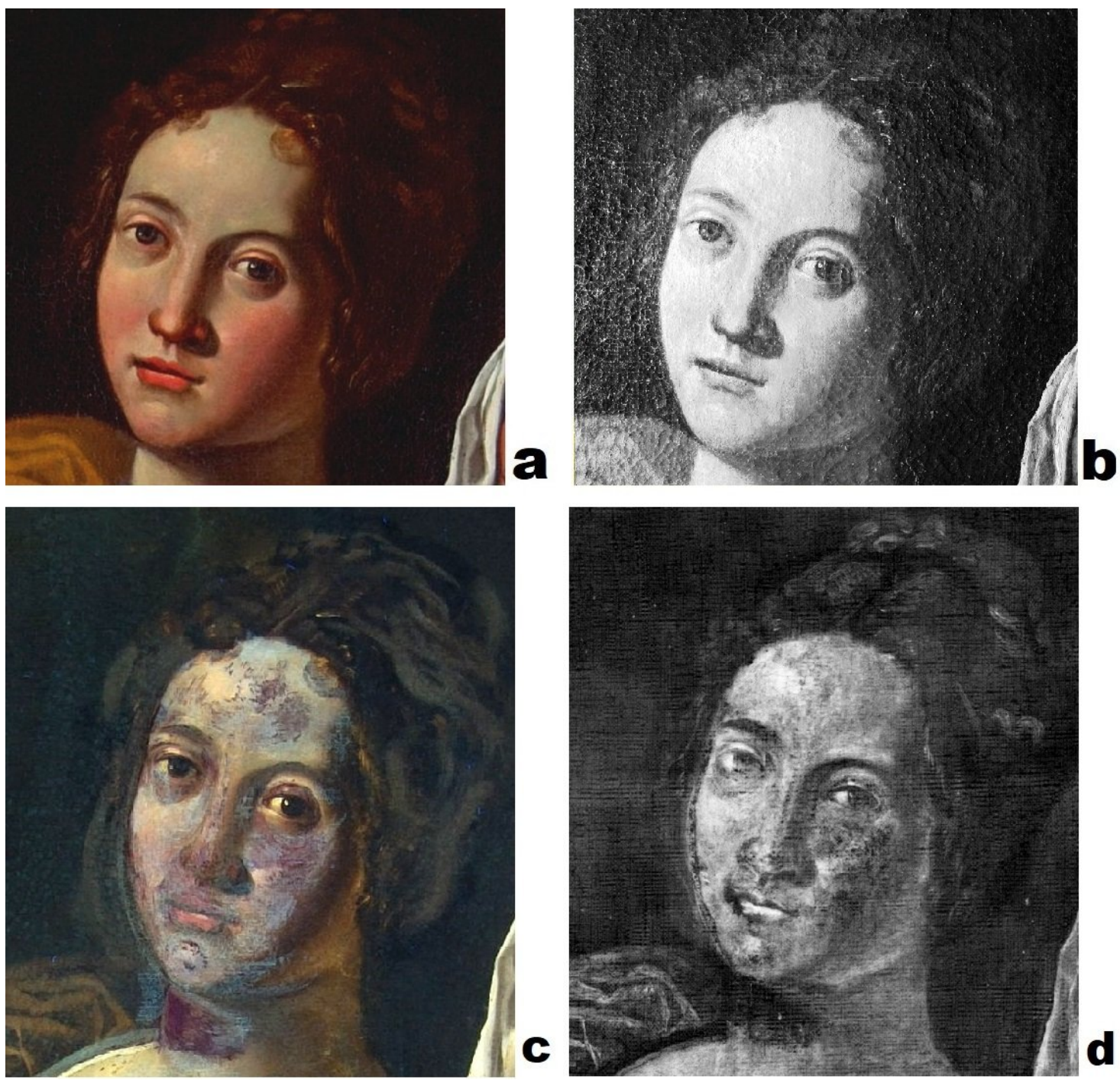

Figure 3. Judith with the head of Holofernes, Judith's face detail. (a) Diffuse light photography. (b) Raking light photography. (c) UV light photography. (d) X radiography, acquired at $24 \mathrm{kV}, 19 \mathrm{~mA}, 1 \mathrm{~s}$ (see Section 2.1).

In Figure 4, the UV fluorescence photography and the X-radiography are shown. In the first image (a), the organic materials are highlighted. Old varnish looks as a green opaque layer on the painted surface. It is evident from this picture that it was not uniform, but in some areas, it was absorbed by the underlying material, e.g., in the red dress of Judith, the darker areas were still covered by the varnish, while in the lighter ones, it seemed to be absorbed.

The peculiarity of $X$-radiography (Figure $4 \mathrm{~b}$ ) is to give evidence of the presence of radiopaque pigments with high $\mathrm{Z}$ elements. These materials are present in all the lighter hues, in which it is possible to delineate single brushstrokes, the pictorial layer being thick.

Focusing on the detail of Judith's face (Figure 3), the information obtained with the two imaging techniques was complementary. In Figure 3c, the UV light underlines the presence of darker purple areas, due to non-fluorescent materials. These materials are localized only on Judith's face and refer to modern pigments due to restoration. 
In Figure $3 d$, the radiography showed the missing of the original radiopaque materials almost in the same areas of the restoration, highlighted by the UV fluorescence, as in the neck of Judith, due to the use of modern and light $\mathrm{Z}$ element pigments. Furthermore, in other areas of the face, the original materials were still present under the restoration ones. Focusing on the left side of the face, it is possible to recognize that the border of the face was shifted to the right, and the surface seemed to be scratched. This area corresponds to the craquelure, as seen in raking light detail (Figure $3 b$ ).

The images obtained with UV fluorescence and X-radiography guided the choice of XRF points, recognizing the restored areas from the original parts.
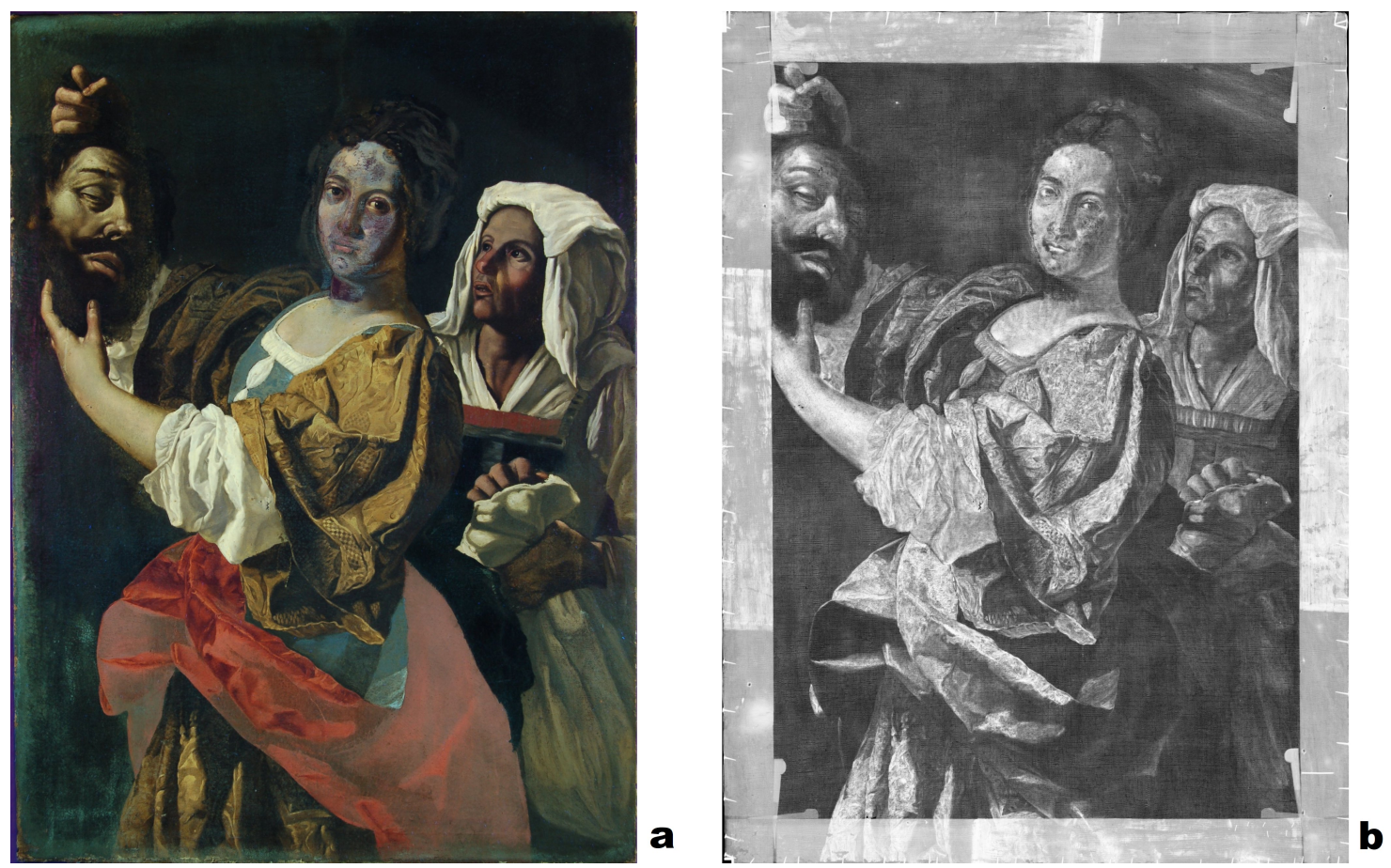

Figure 4. Judith with the head of Holofernes. (a) UV light photography. (b) X radiography, obtained by the stitching of 266 images acquired at $24 \mathrm{kV}, 19 \mathrm{~mA}, 1 \mathrm{~s}$ (see Section 2.1).

\subsection{Spot Analysis}

The X-ray fluorescence analysis was performed on 74 selected points (Figure 2), considering the colors and the presence of retouches due to restoration. In Table 1, a summary of the results obtained for each color is reported. 
Table 1. Table of the elements revealed by the XRF analysis for color. The elements are presented in decreasing order of cps (counts per second). The measurements were taken at $50 \mathrm{kV}, 700 \mu \mathrm{A}, 60 \mathrm{~s}$, in air. In parenthesis () are the elements not found in all the samples.

\begin{tabular}{lll}
\hline Color & Elements (cps Decreasing) & Interpretation \\
\hline White & $\mathrm{Pb}, \mathrm{Fe}, \mathrm{Ca}, \mathrm{Cu}, \mathrm{Mn})$ & Lead White \\
Yellow & $\mathrm{Pb}, \mathrm{Fe}, \mathrm{Sn}, \mathrm{Ca}, \mathrm{Sb}, \mathrm{Zn}, \mathrm{Cu}, \mathrm{Mn}$ & Naples Yellow and Lead-Tin Yellow \\
Blue & $\mathrm{Pb}, \mathrm{Fe}$ and $\mathrm{Ca}, \mathrm{K}, \mathrm{Cu}, \mathrm{Mn}, \mathrm{Ti}, \mathrm{Si}$ & Lapis lazuli \\
Green & $\mathrm{Pb}, \mathrm{Cu}, \mathrm{Fe}, \mathrm{Ca}, \mathrm{Mn}, \mathrm{Ti}$ & Copper based pigment \\
Red & $\mathrm{Hg}, \mathrm{Pb}$ and $\mathrm{Fe}, \mathrm{Ca}(\mathrm{Sr}), \mathrm{K}, \mathrm{Mn}, \mathrm{Ti}, \mathrm{Cu}$ & Cinnabar \\
Brown & $\mathrm{Pb}, \mathrm{Fe}, \mathrm{Ca}, \mathrm{Mn}(\mathrm{Hg}), \mathrm{Ti}, \mathrm{Cu}, \mathrm{Zn}, \mathrm{K}$ & Umber and Cinnabar (hair) \\
Background & $\mathrm{Pb}$ and $\mathrm{Fe}, \mathrm{Ca}, \mathrm{Cu}, \mathrm{Mn}, \mathrm{K}, \mathrm{P}, \mathrm{Zn}, \mathrm{Ti}$ & Umber and Bone Black \\
\hline Judith's skin & $\mathrm{Pb}, \mathrm{Hg}, \mathrm{Fe}, \mathrm{Ca}, \mathrm{Mn}, \mathrm{Ti}, \mathrm{Zn}$ & Lead white (and Minium?), Earths, Cinnabar \\
Holofernes' skin & $\mathrm{Pb}, \mathrm{Hg}, \mathrm{Fe}, \mathrm{Cu}, \mathrm{Ca}, \mathrm{Mn}$ & Lead white (and Minium?), Earths, Cinnabar \\
Maid's skin & $\mathrm{Pb}, \mathrm{Fe},(\mathrm{Hg}), \mathrm{Mn}, \mathrm{Ca}, \mathrm{Ti}$ & Lead white (and Minium?), Earths, (Cinnabar) \\
Judith's restoration & $\mathrm{Pb}, \mathrm{Fe}, \mathrm{Zn}(\mathrm{Hg}), \mathrm{Ti}, \mathrm{Se}), \mathrm{Ca}, \mathrm{Mn}, \mathrm{Cd}), \mathrm{Cu}$ & Zinc White, Titanium White, Cadmium Red \\
\hline
\end{tabular}

The first observation is that for each color, the first element revealed was lead. Furthermore, calcium and iron were present in every point analyzed. These elements could indicate that the ground layer was composed of gypsum, lead white, and an earth, as was typical for a 17th Century painting.

Copper was also present in every spectrum, mainly as a trace element (except for the green areas). This could indicate the presence of a copper-based pigment or an earth rich in copper in the ground layer [5]. For the white areas, the counts per second (cps) of lead were the highest, confirming the use of lead white $\left(2 \mathrm{PbCO}_{3} \cdot \mathrm{Pb}(\mathrm{OH})_{2}\right)$ in the artist's palette $[6,7]$.

In the yellow areas, the presence of lead, tin, and antimony could indicate the use of a specific yellow pigment $\left(\mathrm{PbSnSbO}_{6.5}\right)$, the lead-tin-antimony yellow, used since the 17th Century [8]. The determination of this pigment can be carried out by verifying the correlation between tin and antimony [7]. Lead was not considered because it was present also in the preparation and as a white pigment, so the rate of cps was influenced [7]. The absence of this correlation indicated that for the yellows, two pigments were most likely used: Naples yellow $\left(\mathrm{Pb}_{3}\left(\mathrm{SbO}_{4}\right)_{2}\right)$ and lead-tin yellow Type I $\left(\mathrm{Pb}_{2} \mathrm{SnO}_{4}\right)$, due to the absence of $\mathrm{Si}$, which characterizes lead-tin yellow Type II $\left(\mathrm{Pb}(\mathrm{Sn}, \mathrm{Si}) \mathrm{O}_{3}\right)[6]$.

However, other yellow pigments could be used or mixed, such as yellow ocher $(\mathrm{Fe})$ and organic yellows.

Concerning the blue, the presence of copper was not enough to hypothesize the use of a copper-based pigment. Despite this, the presence of silicon, together with potassium and other trace elements, suggested the use of lapis lazuli $\left(3 \mathrm{Na}_{2} \mathrm{O} \cdot 3 \mathrm{Al}_{2} \mathrm{O}_{3} \cdot 6 \mathrm{SiO}_{2} \cdot 2 \mathrm{NaS}\right.$ with $\mathrm{CaCO}_{3}$ and $\left.\mathrm{FeS}_{2}\right)$ [9]. An iron blue pigment was excluded due to the strong correlation between iron and manganese, suggesting the use of an umber earth [7] to darken the color, as will be explained later.

In the green areas, instead, copper was one of the main elements, suggesting that the use of a copper-based pigment was the more plausible hypothesis. To identify clearly which one of the various copper green pigments available in the 17th Century (as malachite, verdigris, and copper resinate) [9] was used, molecular spectroscopy techniques should be employed.

The main element present in red areas of the painting was mercury, so there was a clear indication for the use of cinnabar $(\mathrm{HgS})$, the only ancient pigment composed of this element [6]. However, the presence of lead could refer both to lead white, from the preparation layer or employed to lighten the hue, and to minium $\left(\mathrm{Pb}_{3} \mathrm{O}_{4}\right)$ or another lead-based pigment, probably mixed with or underlying cinnabar. For the red as well, a good correlation between iron and manganese suggested the use of an umber earth for the darker areas. 
Browns are characterized by iron and manganese between the main elements. As reported in the literature $[5,7,8,10]$, red and yellow earth pigments are mainly colored by iron oxides and/or hydroxides and often contain other minerals such as quartz, clay, etc. Manganese oxides or hydroxides are present in brown earths and umbers. The ratio between iron and manganese determines the hue of the color.

We looked for the correlation between Fe and Mn counts in order to obtain an indication about the use of umber pigments. In Figure 5, we report all the points in which Fe and Mn were revealed, where at least three different and statistically-significant $\left(R^{2}>0.96\right)$ correlations were shown, pointing out three umber hues.

In Judith's hair, the presence of mercury indicated that the umber was mixed with cinnabar to obtain a more reddish brown.

Considering the darker brown of the background, the detection of phosphorus could be related to the use of bone black, the carbon-based black obtained through the calcination of animal bones, thus containing calcium phosphate [11]. The XRF technique working in air was blind to all the elements with $\mathrm{Z}$ lower than silicon, so carbon could not be detected [7]. However, the presence of P revealed only for this dark hue was a clue for the use of bone black.

To characterize fully the presence of this carbon-based pigment, IR reflectance spectroscopy (a noninvasive and in situ technique) was applied with good results [11].

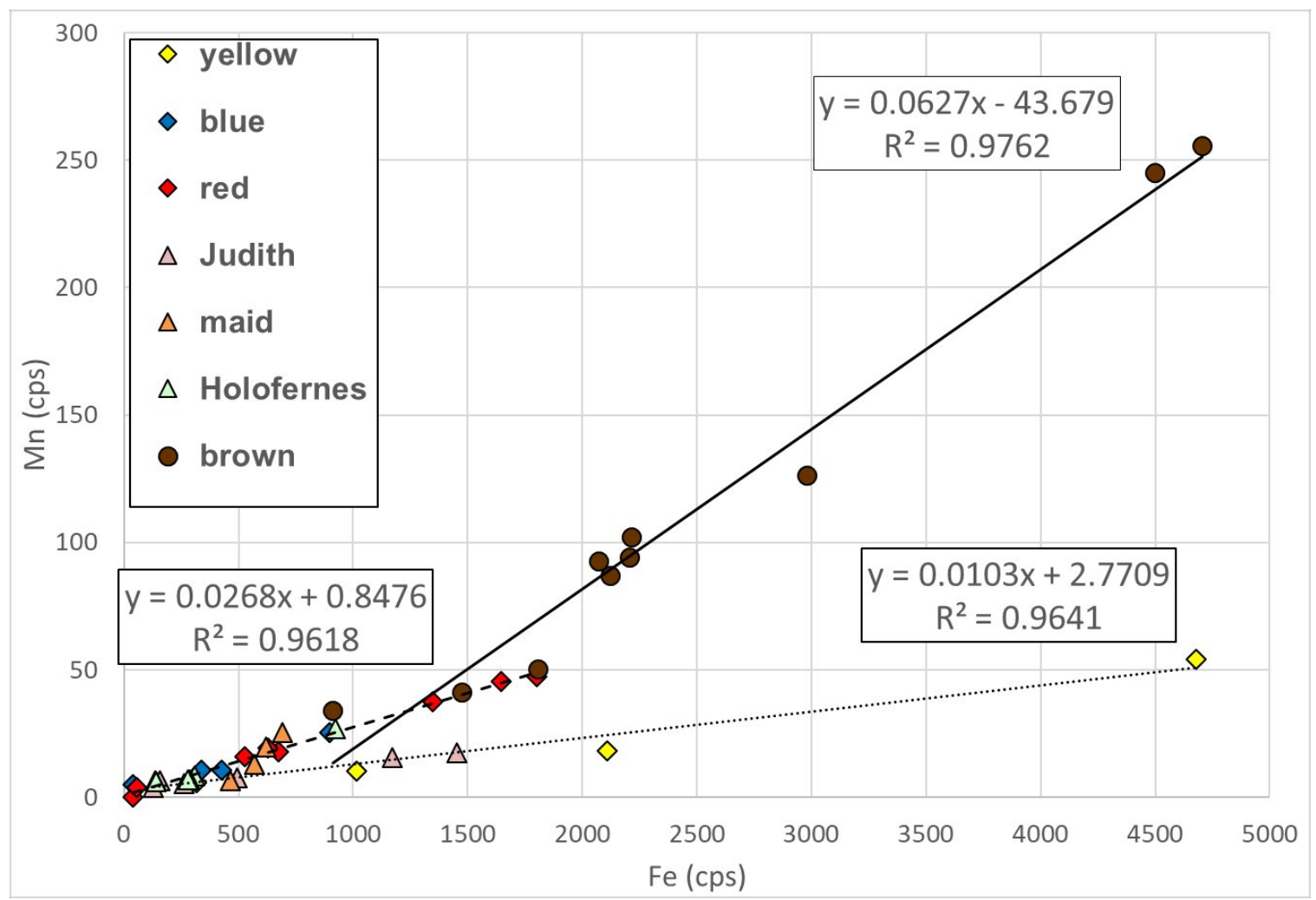

Figure 5. Graph of the cps of Fe ( $x$ axis) and cps of Mn ( $y$ axis) for all the colors. The three lines indicate the correlation between Fe and Mn: continuous line for brown, fragmented line for blue, red for the skin of Holofernes and the maid, and finally, the dotted one for yellow and the skin of Judith. The rates of Mn are higher for brown points, and the correlation with Fe is really good $\left(R^{2}=0.98\right)$. For the other hues, the correlation is still present and is different for yellow and Judith's skin (dotted line) from the other colors (fragmented line). 
The most interesting data concerned the flesh tones of the three characters, focusing on Judith's head, which is the most debated area of the painting. For all of them, lead, mercury, iron, and manganese were detected, suggesting the mixture of lead white and potentially minium, cinnabar, and earths, including umber for the correlation of iron and manganese. The use of minium must be confirmed with other techniques, as XRF cannot discriminate between the lead pigments.

For Holofernes's head, copper was revealed as well. In this case, the artist probably used a copper green to obtain a deathly pale skin.

Focusing on Judith's head, the artistic palette seemed to be the same as the rest of the painting and, for this reason, we can infer the period of realization to be probably the same.

Thanks to UV fluorescence photography and X-radiography, it was possible to analyze the restoration materials. The analyzed points concerned Judith's skin and parts of the restoration materials overlapping the original ones; hence, it was not surprising to find lead, iron, and the other elements already discussed. What is relevant, instead, was the detection of zinc and titanium as the main elements for all the restored areas, which could refer to zinc white $(\mathrm{ZnO})$ and titanium white $\left(\mathrm{TiO}_{2}\right)$, two modern pigments used since the second quarter of the the 19th Century [12] and 1916, respectively [13].

Furthermore, the restoration on the red lips of Judith revealed cadmium and selenium, possibly suggesting the use of cadmium red $(\mathrm{Cd}(\mathrm{S}, \mathrm{Se}))$, another modern pigment employed since 1917 [12].

The detection of these three modern pigments, zinc white, titanium white, and cadmium red, indicated that the restoration was performed during the 20th Century.

To conclude, a preliminary interpretation about the identification of the artistic materials was explained, even if there was no information about the use of organic materials, such as red lacquers and other organic pigments. The use of other techniques would help to characterize these materials and to identify clearly the presence of other pigments, such as minium and copper green pigments.

\section{Conclusions}

Concerning the question posed by art historians about Judith's face, UV fluorescence and X-ray radiography gave complementary answers. The contour was reshaped, possibly after a complete scratch of the visage. However, there was no evidence of a previous face. Probably, due to this change, Judith's face remained the most delicate part of the painting, motivating a restoration in the 20th Century.

Finally, XRF allowed preliminary reconstruction of the majority of the artistic palette and the restoration in the 20th Century.

To conclude, the obtained data improved the knowledge of the painting from a material and executive point of view. The results seem to indicate that, if two artists worked on this painting, they both used art materials compatible with the 17th Century.

Author Contributions: Conceptualization, F.P.; validation, F.P.; investigation, S.B., A.I., and F.P.; resources, F.P.; data curation, S.B., A.I. and F.P.; writing, original draft preparation, A.I.; writing, review and editing, A.I. and F.P.; visualization, A.I.; supervision, F.P.; project administration, F.P.; funding acquisition, F.P.

Funding: This research was funded by a private citizen.

Acknowledgments: We kindly thank Francesca Cappelletti, Department of Human Science of the University of Ferrara, for starting the study on this painting.

Conflicts of Interest: The authors declare no conflict of interest.

\section{Abbreviations}

The following abbreviations are used in this manuscript: 


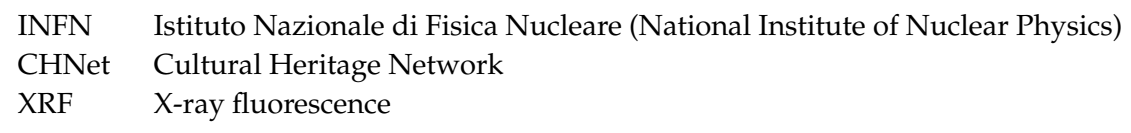

\section{References}

1. Ward Bissel, R. Artemisia Gentileschi, a new documented chronology. Art Bull. 1968, 50, $153-168$.

2. Agnati, T. Artemisia Gentileschi. Art Doss. 2003, 172, 1-52.

3. Biscottin, P. Orazio Gentileschi e aiuti. In Artemisia Gentileschi Storia di una Passione; Mostra Palazzo Reale; $240 r e$ Cultura: Milano, Italy, 2011; p. 138.

4. Impallaria, A.; Evangelisti, F.; Petrucci, F.; Tisato, F.; Castelli, L.; Taccetti, F. A new scanner for in situ digital radiography of paintings. Appl. Phys. 2016, 122, 1043. [CrossRef]

5. Berrie, B.H. Artist's Pigments. A Handbook of Their History and Characteristics; National Gallery of Art: Washington, DC, USA, 2007; Volume 4.

6. Roy, A. Artist's Pigments. A Handbook of Their History and Characteristics; National Gallery of Art: Washington, DC, USA, 1993; Volume 2.

7. Seccaroni, C.; Moioli, P. Fluorescenza X. Prontuario per l'analisi XRF Portatile Applicata a Superfici Policrome; Nardini Editore: Firenze, Italy, 2004.

8. Eastaugh, N.; Walsh, V.; Chaplin, T.; Siddall, R. Pigment Compendium-A Dictionary of Historical Pigments; Elsevier: Oxford, UK, 2008.

9. Bevilacqua, N.; Borgioli, L.; Adrover Gracia, I. I Pigmenti Nell'arte Dalla Preistoria alla Rivoluzione Industriale; il Prato: Saonara (PD), Italy, 2010.

10. Montagner, C.; Sanches, D.; Pedroso, J.; Joao Melo, M.; Viarigues, M. Ochres and earths: Matrix and chromophores characterization of 19th and 20th century artist materials. Spectrochim. Acta A 2013, 103, 409-416. [CrossRef]

11. Daveri, A.; Malagodi, M.; Vagnini, M. The Bone Black pigment identification by noninvasive, in situ infrared reflection spectroscopy. J. Anal. Methods Chem. 2018, 6595643. [CrossRef]

12. Feller, R.L. Artist's Pigments. A Handbook of Their History and Characteristics; National Gallery of Art: Washington, DC, USA, 1986; Volume 1.

13. West FitzHugh, E. Artist's Pigments. A Handbook of Their History and Characteristics; National Gallery of Art: Washington, DC, USA, 1987; Volume 3.

(c) 2019 by the authors. Licensee MDPI, Basel, Switzerland. This article is an open access article distributed under the terms and conditions of the Creative Commons Attribution (CC BY) license (http:/ / creativecommons.org/licenses/by/4.0/). 